\title{
FECALOMA GIGANTE EN UN PACIENTE ADOLESCENTE*
}

Drs. Gino Caselli M. ${ }^{1}$, Cecilia Besa C. ${ }^{2}$, Rodrigo Miguieles C. ${ }^{1}$

${ }^{1}$ Unidad de Coloproctología, Departamento de Cirugía Digestiva.

2 Departamento de Radiología.

Pontificia Universidad Católica de Chile.

Santiago, Chile.

\section{Giant fecaloma in an adolescent patient}

Paciente de 19 años, con antecedentes de agenesia anorrectal operada y constipación crónica refractaria, que ingresa a nuestro centro asistencial por un cuadro de 3 semanas de evolución de ausencia de deposiciones e importante distensión abdominal. Radiografía de abdomen simple muestra gran distensión de asas de colon sigmoides. Se le realiza una proctoclisis digital y uso de enemas evacuantes sin resultado exitoso. La tomografía computada (TC) de abdomen y pelvis demostró signos de una obstrucción intestinal caracterizados por una acentuada dilatación del colon izquierdo, transverso, con material fecal organizado y distensión del recto. Además descartó la presencia de una masa intralu-
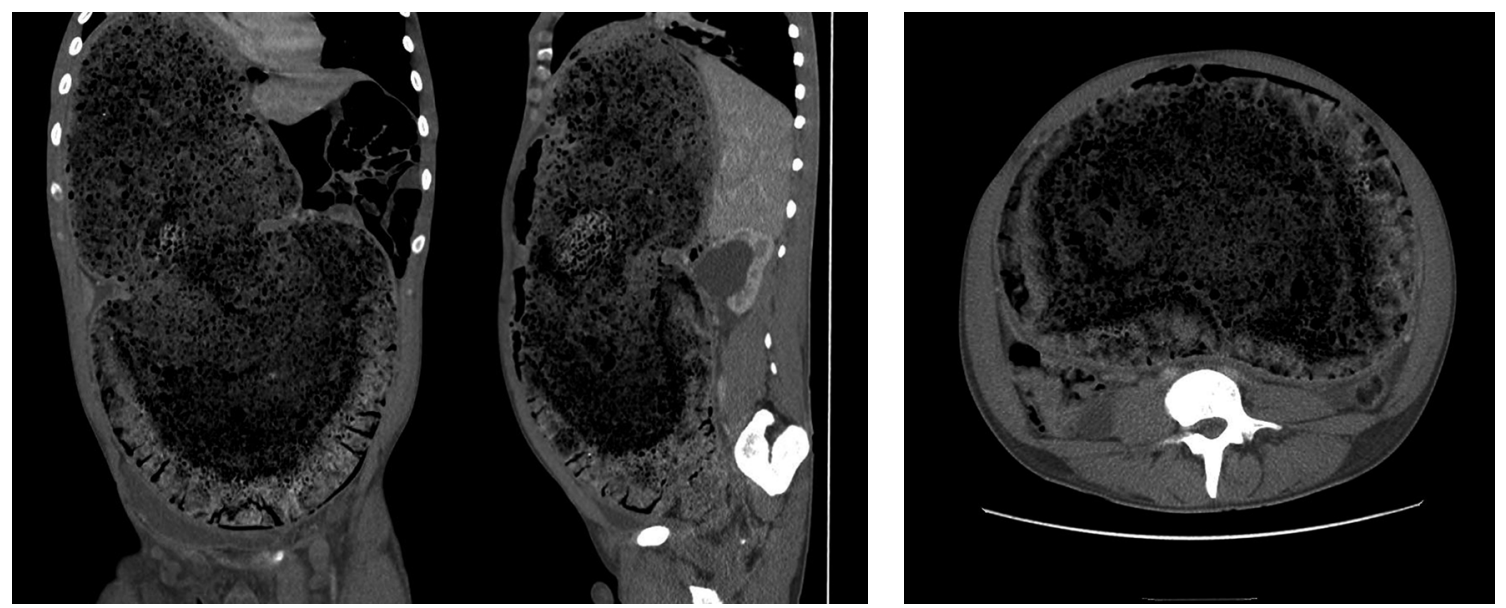

Figuras 1-2. Imágenes axiales de TC que demuestran signos de obstrucción intestinal con dilatación acentuada de asas de colon. Nótese la extensión del material fecal impactado en el recto y colon distal como causa de la obstrucción, con una compresión extrínseca del hígado así como una importante dilatación secundaria de la pelvis renal izquierda.

*Recibido el 2 de octubre de 2013 y aceptado para publicación el 28 de diciembre de 2013.

Los autores no refieren conflictos de interés.

Correspondencia: Dr.Gino Caselli M.

gcaselli@uc.cl 
minal o estenosis distal como la causa obstructiva. El paciente fue sometido a un doble vaciamiento por vía transanal bajo anestesia general, manejado posteriormente con fluidos y ablandador de deposiciones.

Un fecaloma es una masa de heces que se acumula y ocurre de forma más frecuente en el colon distal y el recto ${ }^{1}$, presentando una consistencia mucho más dura que la impactación fecal debido fundamentalmente a la coprostasia. Aunque los fecalomas son más frecuentes en ancianos, constipados o pacientes con lesiones medulares, la formación de un fecaloma gigante que no responde a terapia conservadora es un evento poco frecuente en pacientes jóvenes. Los fecalomas son usualmente fáciles de manejar médicamente con laxantes, enemas o una proctoclisis digital, por lo que la anestesia general es requerida esporádicamente ${ }^{2}$. Algunas de las complicaciones severas secundarias a la existencia de un fecaloma son el compromiso ventilatorio, la perforación intestinal y la uropatía obstructiva ${ }^{3}$.

\section{Referencias}

1. Yucel A, Akdogan R, Gucer H. A Giant abdominal mass: Fecaloma. Clin Gastroenterol Hepatol. 2012;10:e9-e10. Doi:10.1016/j.cgh.2011.06.030.

2. Abella M, Fernández A. Large Fecalomas. Dis Colon Rectum 1967;10:401-4.

3. Altomare D, Rinaldi M, Sallustio P, Armenise N. Giant fecaloma in an adult with severe anal stricture caused by anal imperforation treated by proctocolectomy and ileostomy: Report of a case. Dis Colon rectum 2009;52:534-7. 